\title{
Review \\ Outdoor Air Quality of Environments Used for Exercise and Sports Practice: An Analysis of Scientific Production through Bibliometric Analysis
}

\author{
Alexandro Andrade *(D), Fábio Hech Dominski and Guilherme Torres Vilarino $\mathbb{D}$ \\ Laboratory of Sport and Exercise Psychology, Center of Health and Sport Science, Santa Catarina State University, \\ Florianópolis, Santa Catarina 88080-350, Brazil; fabio.dominski@udesc.br (F.H.D.); \\ guilherme.vilarino@udesc.br (G.T.V.) \\ * Correspondence: Alexandro.andrade.phd@gmail.com
}

Citation: Andrade, A.; Dominski, F.H.; Vilarino, G.T. Outdoor Air Quality of Environments Used for Exercise and Sports Practice: An Analysis of Scientific Production through Bibliometric Analysis. Appl. Sci. 2021, 11, 4540. https:// doi.org/10.3390/app11104540

Received: 28 February 2020

Accepted: 27 March 2020

Published: 17 May 2021

Publisher's Note: MDPI stays neutral with regard to jurisdictional claims in published maps and institutional affiliations.

Copyright: (c) 2021 by the authors. Licensee MDPI, Basel, Switzerland. This article is an open access article distributed under the terms and conditions of the Creative Commons Attribution (CC BY) license (https:/ / creativecommons.org/licenses/by/ $4.0 /)$.
Featured Application: Outdoor air quality of environments used for exercise and sports practice has been a concern for researchers for about 50 years, increasing from 2009 onward, mainly produced by researchers from institutions in the US and China, with focus on subjects related to human health.

Abstract: Thus, far, in the Environmental Science field, there appears to be only one previous bibliometric analysis of scientific production with regard to exercise and sports practice, performed in indoor environments. This study investigates and analyzes scientific production related to outdoor air quality of environments that are used for exercise and sports practice through a bibliometric analysis. Five databases were searched in March 2020. A bibliometric analysis was performed for authors, institutions and countries, in relation to publication year, language, citations, theme, and analysis of publication keywords. Of the 2401 screened studies, 106 satisfied the inclusion criteria. The first work was published in 1967. A high number of studies (85.8\%) were published after 2008. The United States (US) accounted for most of the performed studies, followed by China. The author keywords associated with the words "pollutants", "human health", and "exercise/sports" were the most commonly used. A total of 59 journals had been published on this subject, and most of these were in the area of medicine. It was observed that most of this scientific production was developed by researchers from institutions in the US and China. The publications focused on pollutants and subjects related to human health and sports.

Keywords: bibliometrics; air pollution; air pollutants; environmental pollution; health

\section{Introduction}

Air pollution represents a serious risk to human health, and the effects of exposure to pollution have been investigated in a variety of circumstances [1-3], mainly with regard to cardiovascular and respiratory health $[4,5]$. Along with pollution, physical inactivity is one of the major risk factors for population morbidity and mortality [6], and it is the fourth risk factor for overall mortality [7]. It is estimated that $23 \%$ of the population (one in four adults) does not follow recommendations regarding weekly physical activity, thus being characterized as insufficiently active [7]. The practice of regular physical exercise has shown positive results for several aspects of human health [8-10]; the most common recommendation advises that individuals should accomplish 150 minutes of moderately intensive physical activity per week [11].

Researchers' interest in the relationship between pollution and physical activity has increased due the contrast between the benefits promoted by exercise and the potential risks to human health that are associated with such practices in unhealthy environments $[12,13]$. Exercise causes physiological changes in the human body; these changes include increased 
ventilation and airflow velocity, inhalation of air through the mouth (and not through the nasal mechanisms), and changes in lung diffusion capacity [14]. These changes may facilitate the transport of greater amounts of pollutants into the deeper parts of the respiratory system, thus increasing the risks to health. Thus, the importance of studies on air pollution and its implications for exercise and sports-especially in outdoor environments, where the practitioner's exposure to pollutants and the risks to health are greater [15] —is evident.

Air pollution can discourage people from engaging in exercise and outdoor sports because human exposure to pollution is related to increased blood pressure [15-17], decreased lung function, respiratory symptoms $[18,19]$, and reduced ability to exercise and maintain optimum performance [20].

It is important to gain a comprehensive understanding of the scientific production of outdoor air quality of environments used for exercise and sports practice; this could help researchers understand the evolutions, trends, and emerging themes in this research field. In this way, it could help researchers to point out knowledge gaps in the field. From a quantitative perspective, bibliometric analyses offer an overview of research areas [21], thus contributing to the development of future studies.

We are aware of only one previous bibliometric analysis of scientific production related to physical exercise and sports practice in the Environmental Science field; however, this analysis was related to exercise and sports practice performed in indoor environments [22]. Our hypothesis is that there would be more studies regarding the use of outdoor environments for such activities than indoor environments.

Therefore, the aim of this study was to investigate and analyze scientific production related to outdoor air quality of environments used for exercise and sports practice by using a bibliometric analysis. We performed an analysis of relevant publications, authors, and journals.

\section{Materials and Methods}

This bibliometric analysis was based on the work of Andrade et al. [22] and Coimbra et al. [23].

\subsection{Search Strategy}

The search for studies was performed using the following electronic databases: SCOPUS, Scientific Electronic Library Online (SciELO), SPORTDiscus, Medical Literature Analysis and Retrieval System Online (MEDLINE) via PubMed, and Science Direct. We searched these databases using a sample period beginning with their inception and ending in 17 March 2020. The search terms used in the databases were \{"air pollution" OR "air pollutants" OR "air quality" $\}$ AND \{"physical exercise" OR "physical activity" OR "sport" $\}$. The integrated search was conducted in the field of title, abstract, and subject of each database.

\subsection{Eligibility Criteria}

We included (i) original articles; (ii) articles investigating outdoor air quality in environments used for exercise and sports practice; and (iii) full texts published in English. There were no restrictions on the date of publication. We excluded (i) review articles; (ii) articles investigating indoor air quality; and (iii) published papers with only English abstracts that lacked full texts in English.

\subsection{Data Extraction}

The authors independently extracted data from all included studies. We created categories for the bibliometric analysis and discussion. Analyses were carried out using the publication information of the articles, including the year and language of the publication, number of citations in the Web of Science (WoS, Web of Science Group, Clarivate Analytics, Philadelphia, Pennsylvania, USA) (total and average per year), number of citations in all the databases, and number of instances of use in WoS. The length of the study (number of pages), title length (number of words), and the numbers of tables, figures, keywords, 
and references were also analyzed as bibliometric data. In addition to these data, the study financing analysis was performed by identifying funding agencies and their countries, which were reported in the articles. To deepen the analysis of the main themes addressed in the studies, a survey of the keywords cited by the authors was carried out, and categories were created, which were further sub-categorized into clusters and used to describe the associations between words, with a view to identifying those that were more influential and important. We investigated the main pollutants and the exercise context according to the locations where the studies were carried out, such as sporting events, physical activity, sports in general, physical activity during transport, exercise, and others.

The relationships between the authors were also verified by analyzing the number of authors involved, the number of institutions, and the country. Based on these data, we identified the authors who had published the highest number of works on the topic, their respective collaboration networks, and the period of influence of publications. Data related to the journals' impact factors, country, and area were also analyzed. The impact factor (in 2018) and the journal area were obtained through WoS and SCImago sites, respectively.

\subsection{Statistical Analysis}

Data analysis was conducted using "IBM Statistical Package for the Social Sciences" (SPSS) version 20.0. To compare studies published until 2008 and studies published after 2008, we performed independent t-tests and the Mann-Whitney $U$ test in order to obtain the comparison of means regarding the impact factor, the number of citations in WoS, usage count, the number of authors, institutions and countries, length of study and title, and the numbers of tables, figures, keywords, and references. The significance level was defined as $p<0.05$ for all the tests.

\section{Results}

Our search identified 2401 articles, of which the full texts for 170 were reviewed, and 106 met the inclusion criteria. A flowchart of the study selection process is reported in Figure 1.

\subsection{Publications}

The first publication about the topic occurred in 1967 (Figure 2). The study analysis showed that there was an increase in publications on this subject beginning in 2009; in the last decade, 83 studies were published, and these corresponded to $78.3 \%$ of publications. The year with the highest number of publications was 2013 (13 studies). All the studies included in the present study's sample were published in the English language, except one published in Portuguese.

The quantitative analysis of the number of title words, keywords, tables, figures, pages, and references can also be carried out through bibliometric studies [24,25], though this depends on the potential of these results to allow analyses of the scope and depth.

The number of words in the title ranged from six (6) to 34 (median of 14). Relevant keywords started to appear in the studies only from 1994 onward, and in the last few years, the number of keywords was between four and eight. The number of pages ranged from four to 204 (median of 9).

The total number of citations to the published articles was 2,391, with an average of 22.55 (min.0; max.418) citations per document (Table 1). The usage count is a measure provided by WoS; it measures interest in a platform-specific item. This information reflects the number of times an article has met the user's information needs, and it is updated daily. 


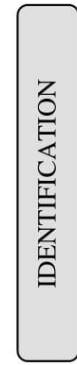

2401 records identified through database search: SciELO (123)

Science Direct (191)

MedLine (314)

SportDiscus (566)

Scopus (1207)

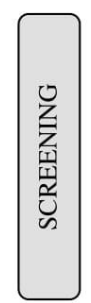

2005 studies after duplicate records excluded

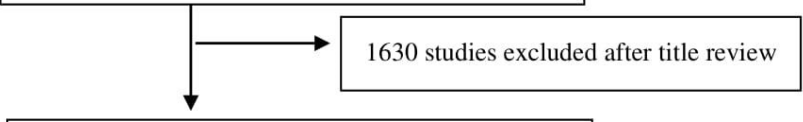

375 studies selected to abstract review

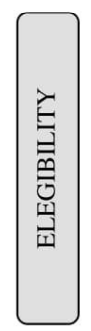

205 studies excluded after abstract review

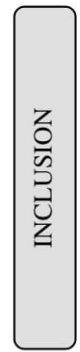

64 studies excluded after full-text review Study in indoor environment (14)

- Full-text not available (12)

Study not treat outdoor environment (9)

- Study not treat air pollution (10)

Study design (7)

Figure 1. PRISMA flow diagram illustrating the literature research and selection process.

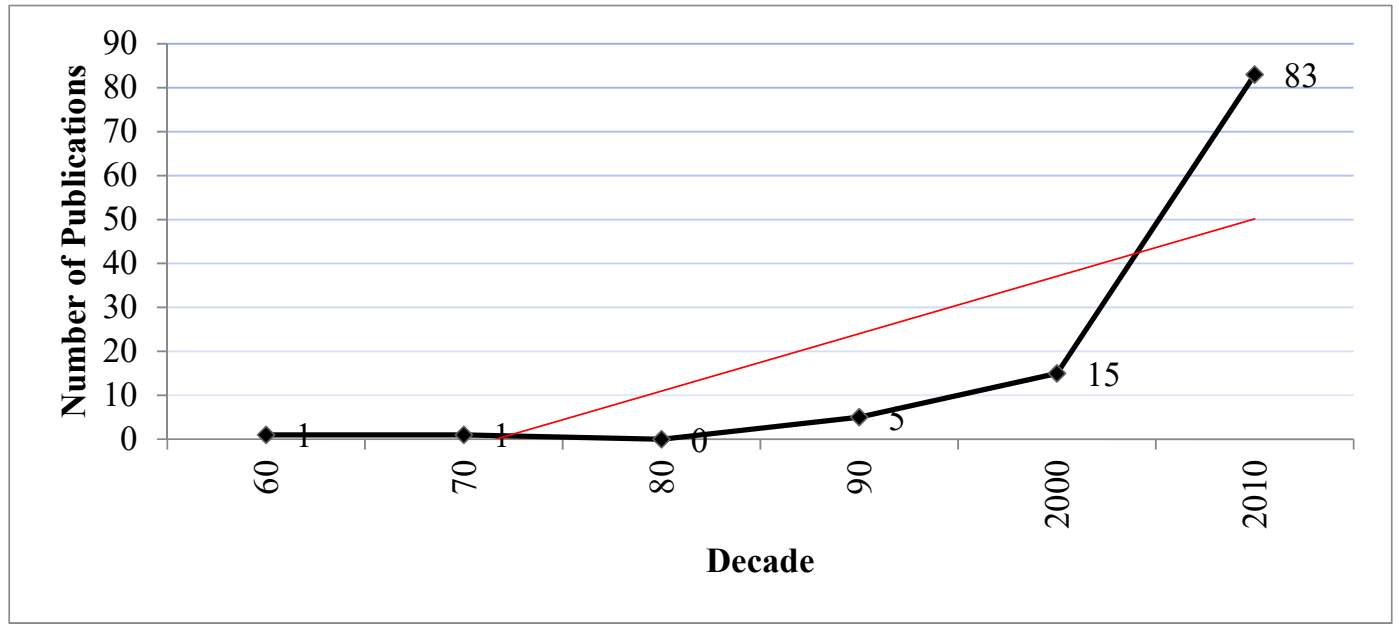

* The linear adjustment of the number of publications is represented by the red line.

Figure 2. Distribution of the number of publications per decade. 
Table 1. Length of title, keywords, and number of tables, figures, and pages of studies about outdoor air quality of environments used for exercise and sports practice.

\begin{tabular}{ccccc}
\hline & Mean & Median & Minimum & Maximum \\
\hline Length of title & 15.12 & 14 & 6 & 34 \\
Number of keywords & 5.13 & 5 & 0 & 11 \\
Number of tables & 3.07 & 3 & 0 & 9 \\
Number of figures & 3.77 & 3 & 0 & 30 \\
Number of References & 41.39 & 39 & 5 & 149 \\
Length (pages) & 11.942 & 9 & 4 & 204 \\
Number of citations WoS & 22.70 & 7 & 0 & 418 \\
Number of citations WoS by year & 2.68 & 1.33 & 0 & 427 \\
Citations in all databases & 24.17 & 7 & 0 & 243 \\
Usage Count & 28.57 & 19 & 0 &
\end{tabular}

Among the 106 publications, the most cited was the study by McConnell et al. published in 2002 in the Lancet and presenting 462 citations in the main collection of WoS; this publication also presented the highest average citations per year (24.3) in WoS [26]. This study aimed to evaluate the association between participating in sports teams and the subsequent development of asthma in children. In the study, concentrations of $\mathrm{PM}_{10}$, $\mathrm{PM}_{2.5}, \mathrm{O}_{3}$, and $\mathrm{NO}_{2}$ were monitored. The ten selected studies with the highest amount of citations in WoS are presented in Table 2.

The studies used 411 keywords in total. Most of the studies cited five keywords (min.3; max.11). Figure 3 shows the keywords that were used in at least three studies. The larger size of the source indicates that more studies cited the specific keyword, and the smallest source indicates that the smallest number of studies cited the specific keyword. The most cited keywords were air pollution (20 studies), physical activity (15), and particulate matter (11).

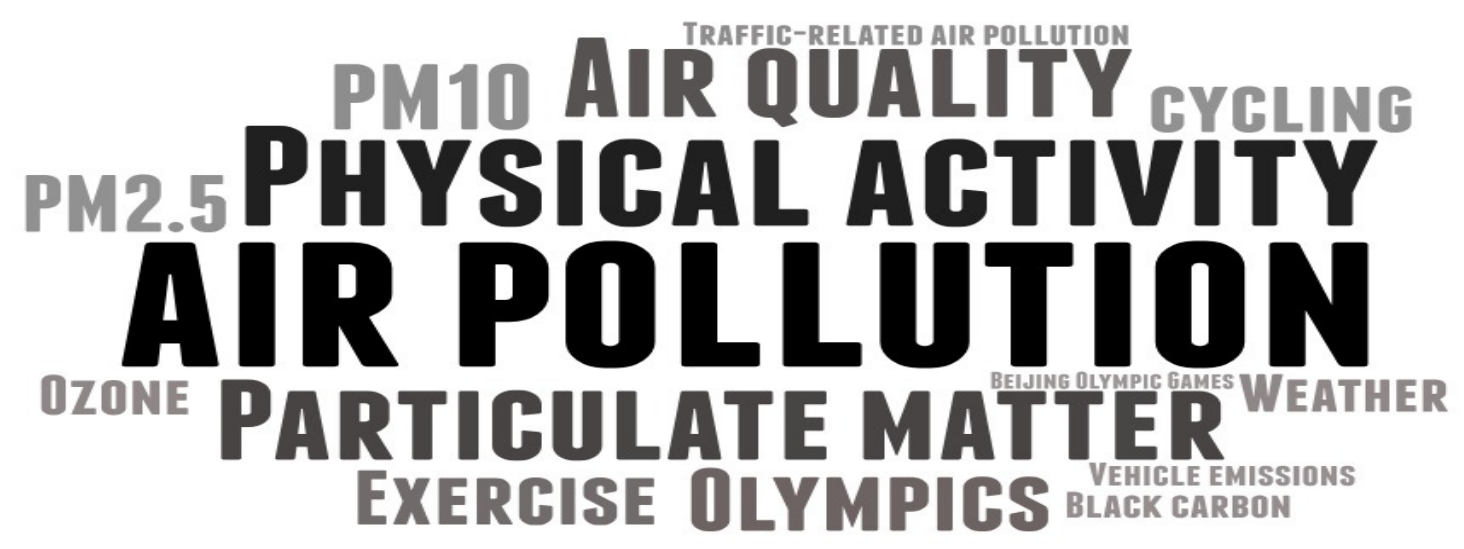

Figure 3. Keywords used in published studies.

The categorization of the keywords into clusters was performed in accordance with the work of Andrade et al. [22]. Most of the keywords were related to pollutants (85), human health (58), and exercise/sports (50). Figure 4 shows the keyword categories, number of related keywords, and examples of words. 
Table 2. Publications with the highest number of citations in WoS.

\begin{tabular}{|c|c|c|c|c|c|}
\hline Title & Journal & Author/Year of Publication & $\begin{array}{c}\text { Wos Citations/Average by } \\
\text { Year }\end{array}$ & Pollutants Investigated & Exercise/Sport Context \\
\hline $\begin{array}{l}\text { Asthma in exercising children exposed to } \\
\text { ozone: a cohort study }\end{array}$ & Lancet & McConnell et al. (2002) [26] & $462 / 24.32$ & $\mathrm{PM}_{10}, \mathrm{PM}_{2.5}, \mathrm{O}_{3}, \mathrm{NO}_{2}$ & Sports \\
\hline $\begin{array}{l}\text { Quantifying the air pollutants emission } \\
\text { reduction during the } 2008 \text { Olympic Games } \\
\text { in Beijing }\end{array}$ & $\begin{array}{c}\text { Environmental } \\
\text { Science \& Technology }\end{array}$ & Wang et al. (2010) [27] & $215 / 19.55$ & $\begin{array}{l}\mathrm{SO}_{2}, \mathrm{NOx} \mathrm{PM}_{10} \\
\quad \mathrm{NMVOC}\end{array}$ & The 2008 Olympic Games \\
\hline $\begin{array}{l}\text { The health risks and benefits of cycling in } \\
\text { urban environments compared with car use: } \\
\text { health impact assessment study }\end{array}$ & $\begin{array}{l}\text { British Medical } \\
\text { Journal }\end{array}$ & Rojas-Rueda et al. (2011) [28] & $203 / 20.30$ & $\mathrm{PM}_{2.5}$ & Transport-cyclism \\
\hline $\begin{array}{l}\text { Association Between Changes in Air } \\
\text { Pollution Levels During the Beijing } \\
\text { Olympics and Biomarkers of Inflammation } \\
\text { and Thrombosis in Healthy Young Adults }\end{array}$ & $\begin{array}{l}\text { Journal of the } \\
\text { American Medical } \\
\text { Association }\end{array}$ & Rich et al. (2012) [29] & $195 / 21.67$ & $\mathrm{PM}_{2.5}, \mathrm{SO}_{2}, \mathrm{NO}_{2}, \mathrm{CO}, \mathrm{O}_{3}$ & The 2008 Olympic Games \\
\hline $\begin{array}{l}\text { Exposure to particulate matter in traffic: A } \\
\text { comparison of cyclists and car passengers }\end{array}$ & $\begin{array}{l}\text { Atmospheric } \\
\text { Environment }\end{array}$ & Panis et al. (2010) [30] & $185 / 16.82$ & PNC, PM2.5 and PM10 & Transport-cyclism \\
\hline $\begin{array}{l}\text { Atmospheric Particulate MatterPollution } \\
\text { during the } 2008 \text { Beijing Olympics }\end{array}$ & $\begin{array}{c}\text { Environmental } \\
\text { Science \& Technology }\end{array}$ & Wang et al. (2009) [31] & $113 / 9.42$ & $\mathrm{PM}_{10}, \mathrm{PM}_{2.5}, \mathrm{PM}_{2.5-10}$ & The 2008 Olympic Games \\
\hline $\begin{array}{l}\text { Healthy neighborhoods: Walkability and air } \\
\text { pollution }\end{array}$ & $\begin{array}{l}\text { Environmental Health } \\
\text { Perspectives }\end{array}$ & Marshall et al. (2009) [33] & $97 / 8.08$ & $\mathrm{NO}, \mathrm{O}_{3}$ & Physical activity \\
\hline $\begin{array}{c}\text { Subclinical responses in healthy cyclists } \\
\text { briefly exposed to traffic-related air } \\
\text { pollution: An intervention study }\end{array}$ & Environmental Health & Jacobs et al. (2010) [34] & $87 / 7.91$ & $\mathrm{PM}_{10}, \mathrm{PM}_{2.5}, \mathrm{UFP}$ & Transport - cyclism \\
\hline $\begin{array}{l}\text { Oxidant Air Pollution and Athletic } \\
\text { Performance }\end{array}$ & $\begin{array}{l}\text { Journal of the } \\
\text { American Medical } \\
\text { Association }\end{array}$ & Wayne et al. (1967) [35] & $79 / 1.46$ & $\mathrm{CO}$ & Sport - Running \\
\hline
\end{tabular}




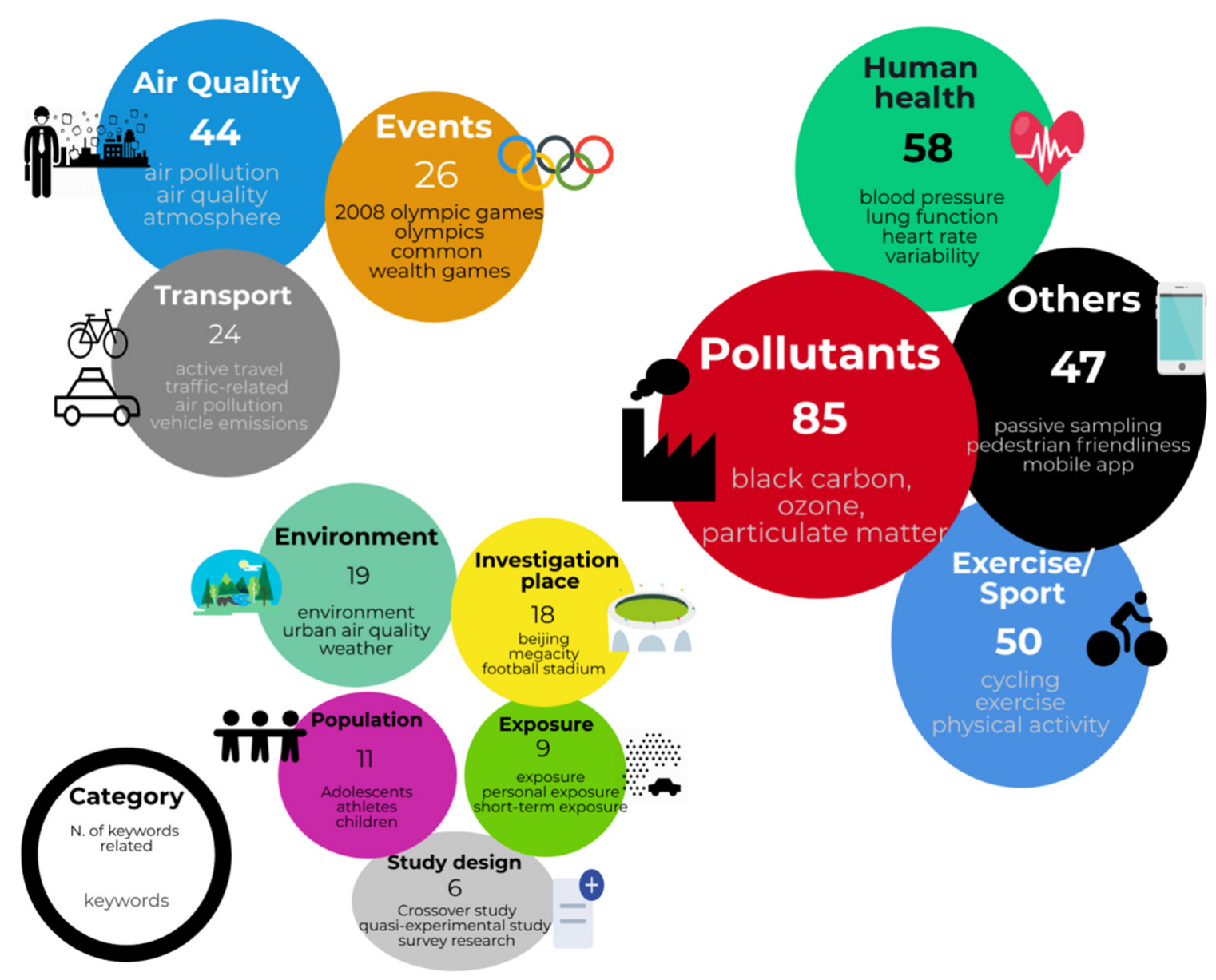

Figure 4. Categories of Keywords.

Regarding the exercise context, most studies were performed during sporting events (39), mainly related to the 2008 Olympic Games in Beijing, China. This was followed by physical activity (22), sports in general (22) such as football and cycling, physical activity during transport (10), exercise (11), physical education classes, and physical fitness tests.

The main pollutants investigated were particulate matter with an aerodynamic diameter smaller than $10\left(\mathrm{PM}_{10}\right)$ and $\mathrm{PM}_{2.5}$, with 43 and 45 studies, respectively. Nitrogen dioxide $\left(\mathrm{NO}_{2}\right)$ was investigated in 34 studies, followed by ozone $\left(\mathrm{O}_{3}\right)$ in 29 studies, $\mathrm{CO}(23)$, $\mathrm{SO}_{2}$ (19), black carbon (17), comfort parameters such as temperature (13) and humidity (8), NOx (5), benzene, $\mathrm{PM}_{1}, \mathrm{PM}$ not specified, and wind speed in 3 studies each. The benzene, toluene, ethylbenzene and xylene (BTEX) and air were analyzed in two studies. Air quality index was analyzed in three studies, and the number of measured parameters ranged from one to eight.

It was observed that $74(69.8 \%)$ studies reported at least one funding agency, while $32(30.2 \%)$ did not present any. Among the studies that presented financing information, $39(36.7 \%)$ presented a financing agency, $15(14.1 \%)$ presented two, ten $(9.4 \%)$ had three agencies, and ten $(9.4 \%)$ presented more than three agencies (Figure 5). 


\section{Funding}

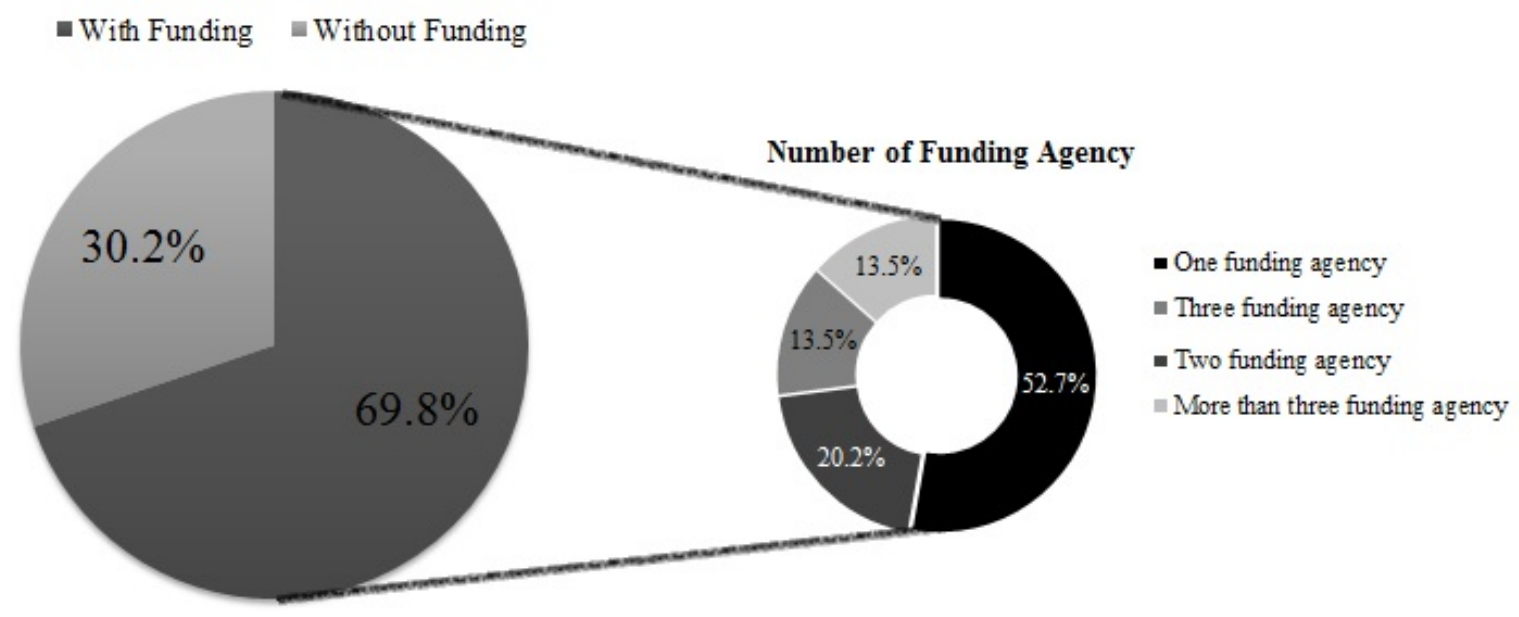

Figure 5. Funding of publications.

Among the 74 funded studies, 96 different funding agencies were reported. The National Natural Science Foundation of China was the agency that funded the largest number of studies, funding eleven studies in total (Table 3). The funding agencies had their headquarters in 17 countries. China and the United States (US) were the countries with the largest number of funding agencies, with 35 and 20 agencies, respectively.

Table 3. The main funding agencies of studies.

\begin{tabular}{|c|c|c|}
\hline Funding Agency & Countries & Number of Studies Funded \\
\hline National Natural Science Foundation of China & China & 11 \\
\hline $\begin{array}{c}\text { Brazilian National Council for Scientific and } \\
\text { Technological Development }\end{array}$ & Brazil & 5 \\
\hline Beijing Council of Science and Technology & China & 3 \\
\hline Chinese Academy of Sciences & China & 3 \\
\hline German Research Foundation (DFG) & Germany & 3 \\
\hline National Basic Research Program of China & China & 3 \\
\hline São Paulo Research Foundation & Brazil & 3 \\
\hline $\begin{array}{l}\text { Belgian science policy under the Science for } \\
\text { Sustainable Development program }\end{array}$ & Belgium & 2 \\
\hline $\begin{array}{l}\text { The National Institute of Environmental Health } \\
\text { Sciences }\end{array}$ & $\begin{array}{l}\text { United } \\
\text { States }\end{array}$ & 2 \\
\hline Health Canada & Canada & 2 \\
\hline Universidad de Los Andes & Colombia & 2 \\
\hline
\end{tabular}

Studies that were published before 2008 had a higher usage count in WoS $(p<0.01)$. More recently, the studies began to feature a greater number of authors, institutions $(p<0.01)$, and countries $(p=0.017)$, as well as longer study lengths in terms of pages $(p<0.01)$ and titles $(p=0.042)$ (Table 4$)$. 
Table 4. Comparison of the averages of the studies published until 2008 and studies published after 2008 (journal impact factor, number of citations in WoS and usage count, the numbers of authors, institutions, and countries, study length and title, and numbers of tables, figures, keywords, and references).

\begin{tabular}{|c|c|c|c|}
\hline \multirow{2}{*}{ Study Characteristics } & Until 2008 & After 2008 & \multirow{2}{*}{$p$} \\
\hline & $\mathrm{n}=15(14.2 \%)$ & $\mathrm{n}=91(85.8 \%)$ & \\
\hline Journal impact factor & 8.95 & 4.38 & 0.145 \\
\hline Citations in WoS & 42.80 & 19.22 & 0.446 \\
\hline Citations in WoS/year & 2.31 & 2.71 & 0.149 \\
\hline Usage count WoS ** & 7.85 & 31.75 & $<0.01$ \\
\hline N. of Authors ** & 3.93 & 6.86 & $<0.01$ \\
\hline N. of Institutions $* *$ & 1.87 & 3.68 & $<0.01$ \\
\hline N. of countries * & 1.13 & 1.76 & 0.017 \\
\hline Length of study (pages) ** & 7.67 & 12.65 & $<0.01$ \\
\hline Length of title * & 13.26 & 15.43 & 0.042 \\
\hline N. of Tables & 2.80 & 3.11 & 0.284 \\
\hline N. of Figures & 2.93 & 3.91 & 0.231 \\
\hline N. of Keywords & 4.37 & 5.22 & 0.118 \\
\hline N. of References ** & 22.60 & 44.48 & $<0.01$ \\
\hline
\end{tabular}

* Significant difference at $p<0.05 .{ }^{* *}$ Significant difference at $p<0.01$.

\subsection{The Authors}

Out of the 559 different authors of the selected studies, the most published were Mark J. Nieuwenhuijsen and Audrey de Nazelle; they had ten and nine studies, respectively. However, most of the researchers (489) had authored only one study. The number of publications per author ranged from 1 to 6 , as shown in Figure 6.

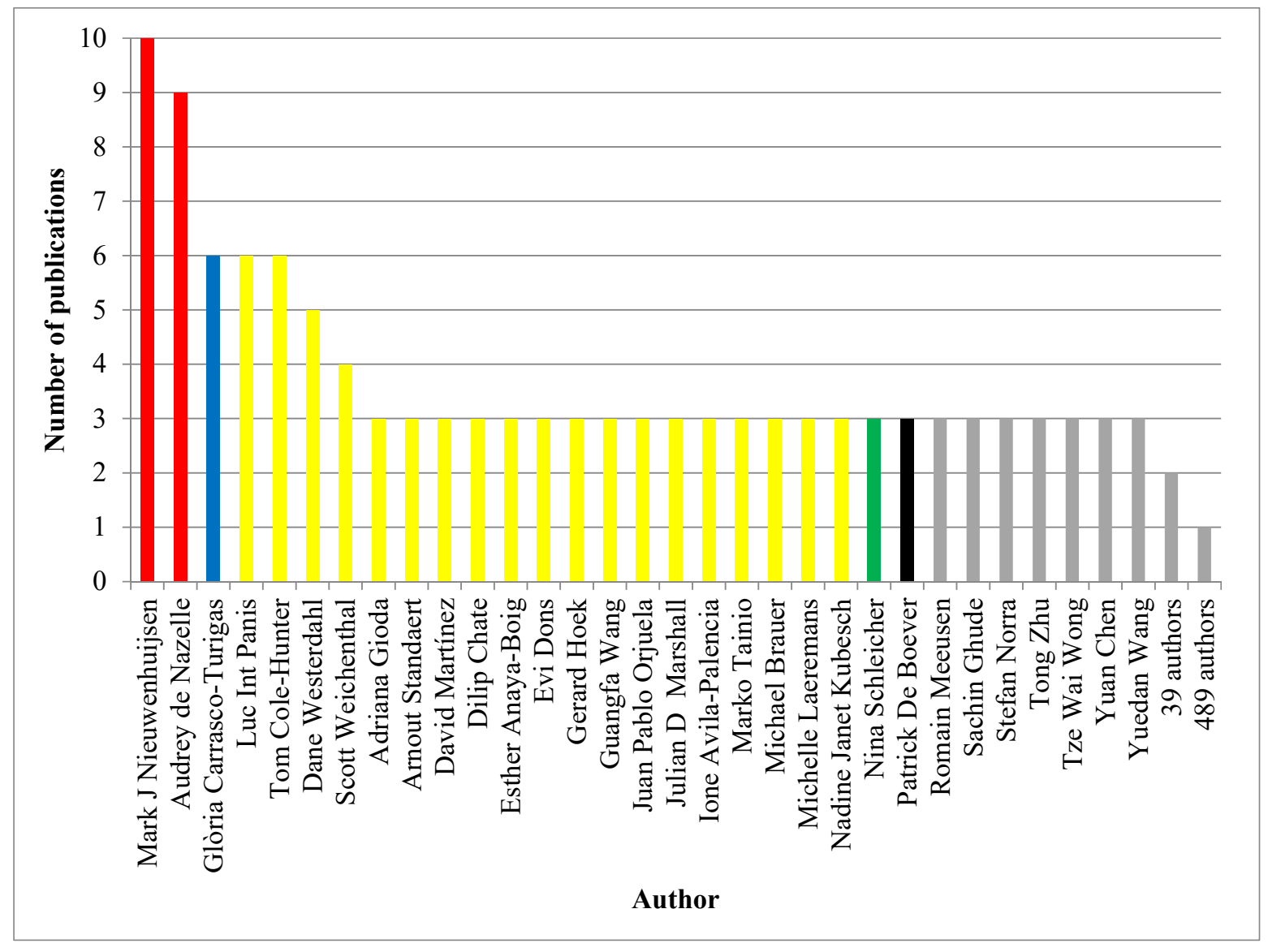

Figure 6. Number of publications by authors who had published studies about the topic. 
The outdoor air quality of environments used for physical exercise and sports is a subject that has been investigated in several countries around the world. Most of the studies were carried out by researchers from institutions in the US (35), China (35), the United Kingdom (12), and Spain (12). The number of origin countries for the institutions per study ranged from one to five. Most of the studies $(63 / 59.4 \%)$ were published by authors from institutions headquartered in only one country; however, some studies had authors with institutional affiliations in at least two countries (43/40.5\%).

Researchers from institutions in 32 countries participated in publications on the subject. It was also observed that, in terms of global geographical distribution, publications on outdoor air quality of environments used for exercise and sports practice were predominant in European countries (present in 56 studies). Figure 7 shows the worldwide geographical distribution of publications on the subject, considering country, continent, and the main institutions.

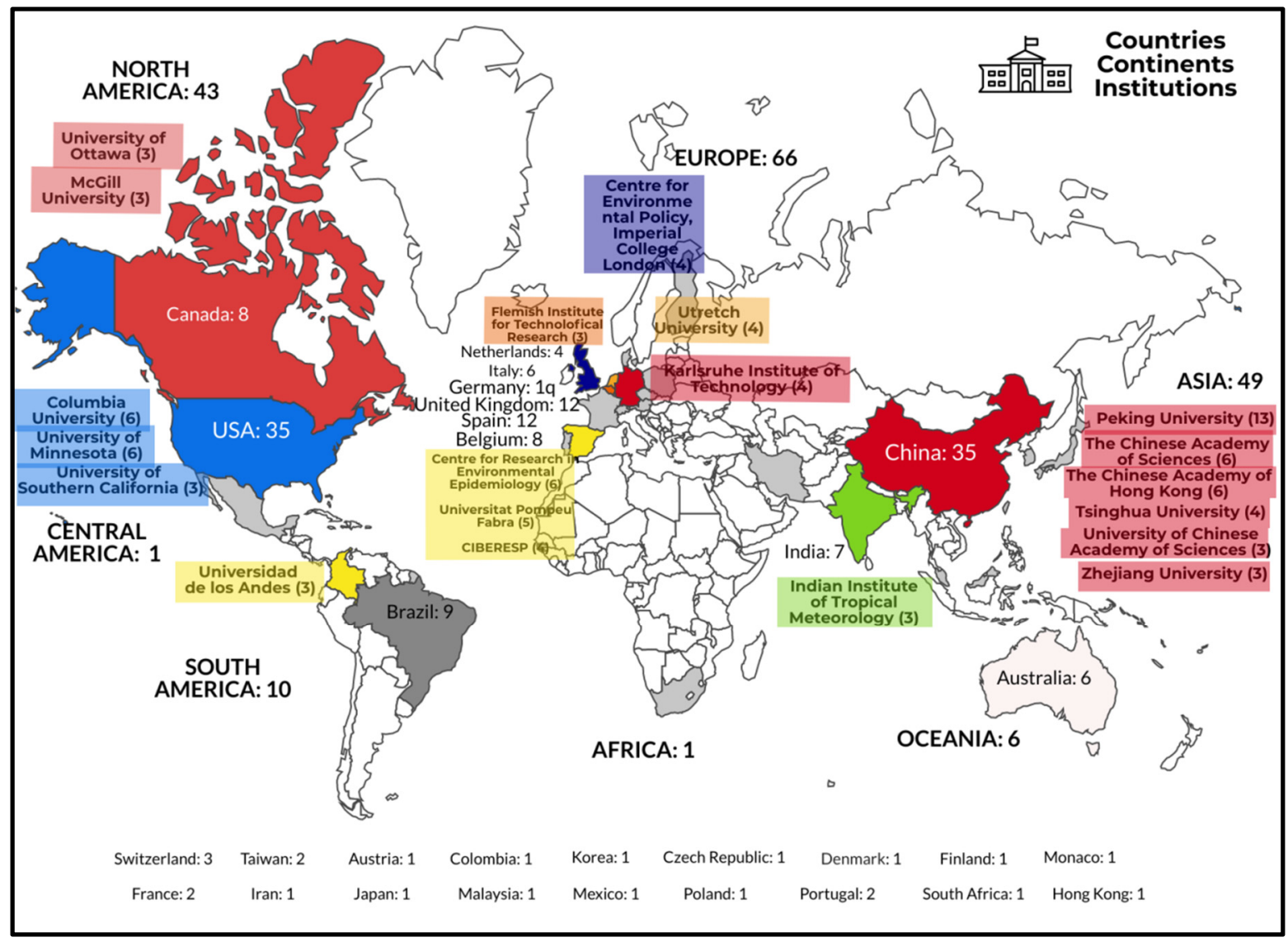

Figure 7. Global geographical distribution of publications: number of publications by continent and country, and institutions with the highest number of publications.

\subsection{Journals}

We observed 59 different scientific journals that published studies on the subject. The journal with the most publications was Atmospheric Environment (11). The impact factor of the journals ranged from 0.12 to 51.27 , and only five journals did not present any impact factor (Table 5). 
Table 5. The number of publications, impact factor, and country and area of the journals.

\begin{tabular}{|c|c|c|c|c|}
\hline $\begin{array}{l}\text { Number of } \\
\text { Publications }\end{array}$ & Journals & FI & $\begin{array}{l}\text { Country of } \\
\text { Journals }\end{array}$ & Journal Area \\
\hline 11 & Atmospheric Environment & 4.01 & Netherlands & $\begin{array}{c}\text { Environmental Science, Earth and } \\
\text { Planetary Sciences }\end{array}$ \\
\hline 8 & Science of the Total Environment & 5.58 & Netherlands & Environmental Science \\
\hline 5 & $\begin{array}{c}\text { Environmental Science \& } \\
\text { Technology }\end{array}$ & 7.14 & EUA & $\begin{array}{l}\text { Chemistry, Environmental Sciences } \\
\text { and Medicine }\end{array}$ \\
\hline 4 & $\begin{array}{l}\text { Environmental Health } \\
\text { Perspectives }\end{array}$ & 7.73 & EUA & Environmental Science, Medicine \\
\hline 4 & Environment International & 7.94 & $\begin{array}{l}\text { United } \\
\text { Kingdom }\end{array}$ & Environmental Science \\
\hline 4 & Environmental Research & 5.02 & EUA & $\begin{array}{l}\text { Biochemistry, Genetics and } \\
\text { Molecular Biology, Environmental } \\
\text { Science }\end{array}$ \\
\hline 3 & Aerosol and Air Quality Research & 2.73 & Taiwan & Environmental Science \\
\hline 3 & Environmental Health & 4.43 & - & Environmental Science \\
\hline 3 & Archives of Environmental Health & - & EUA & Environmental Science \\
\hline 3 & $\begin{array}{l}\text { Journal of Occupational and } \\
\text { Environmental Medicine }\end{array}$ & 1.59 & EUA & Medicine \\
\hline 3 & $\begin{array}{c}\text { Medicine \& Science in Sports \& } \\
\text { Exercise }\end{array}$ & 4.47 & EUA & Health Professions, Medicine \\
\hline 3 & $\begin{array}{c}\text { International Journal of } \\
\text { Environmental Research and } \\
\text { Public Health }\end{array}$ & 2.46 & Switzerland & Environmental Science \\
\hline 3 & PLoS ONE & 2.77 & EUA & $\begin{array}{c}\text { Agricultural and Biological Sciences } \\
\text { Biochemistry, Genetics and } \\
\text { Molecular Biology } \\
\text { Medicine }\end{array}$ \\
\hline 2 & Inhalation Toxicology & 1.73 & $\begin{array}{l}\text { United } \\
\text { Kingdom }\end{array}$ & $\begin{array}{c}\text { Environmental Science } \\
\text { Pharmacology, Toxicology and } \\
\text { Pharmaceutics }\end{array}$ \\
\hline 2 & $\begin{array}{l}\text { International Journal of Behavioral } \\
\text { Nutrition and Physical Activity }\end{array}$ & 6.03 & $\begin{array}{l}\text { United } \\
\text { Kingdom }\end{array}$ & $\begin{array}{c}\text { Health Professions } \\
\text { Medicine } \\
\text { Nursing }\end{array}$ \\
\hline 2 & $\begin{array}{c}\text { Journal of the American Medical } \\
\text { Association }\end{array}$ & 51.27 & EUA & Medicine \\
\hline 1 & 43 journals & $\begin{array}{l}0.128 \text { until } \\
51.27\end{array}$ & 7 countries & - \\
\hline
\end{tabular}

IF: Impact Factor (year 2018)

\section{Discussion}

We aimed to investigate and analyze the international scientific production related to the air quality in outdoor environments used for exercise and sports practice by using a bibliometric analysis. The bibliometric data analyzed were related to publications, authors, and journals.

\subsection{Publications}

Regarding publications, it was observed that growth in terms of number and frequency began from 2009 onward. More than $85 \%$ of the scientific production on the subject was published in recent years (2009-2020). The increased production of pollution-related knowledge is well reported in the literature [36]. Compared to the scientific production on indoor air quality of environments used for exercise and sports practice [22], there were larger numbers of studies analyzing the outdoor environment, as presented in our results.

The first such published study investigated the effect of air oxidation on the athletic performance of 21 runners in Los Angeles in the US [35]. This study is among the ten most cited in WoS from among the selected studies (79 citations). The study with the highest number of citations was developed by McConnell et al. [26]; the authors investigated the 
effects of physical exercise in children with asthma who were exposed to ozone. This demonstrates the relevance and importance of the topic for researchers concerned with this subject area. However, the study by McConnell et al. obtained a small usage count in WoS [27]. Regarding this metric, a study that showed a high level of interest and met the information needs of the users was published by Wang et al. [27]; this study analyzed the reduction of air pollutant emission during the Beijing Olympics. The growing concern about the impact of pollution on the environment, which has even caused political tensions between several countries, shows that researchers from different areas are interested in this subject. This may have contributed to user interest in this paper. In addition, the Olympic Games were mega events with global relevance, and this explains the high level of interest shown by WoS users.

The keyword analysis used in the studies was mainly related to pollutants; this result is an outcome of the findings of the study developed by Andrade et al., which was carried out indoors [22]. Particulate material $\left(\mathrm{PM}_{10}\right.$ and $\left.\mathrm{PM}_{2.5}\right)$, ozone, and black carbon were among the most cited pollutants. On the other hand, in contrast to the findings of the indoor environment studies, the present study showed that several keywords related to human health, such as blood pressure, lung function, and heart rate variability, were investigated in the selected studies. The relationship between air pollution and human health was also evidenced in the most cited publications, in which health risks, health benefits, asthma, and inflammatory biomarkers were investigated.

The size of the study, which was measured in pages, was higher in the most recent publications (2009-2020) compared to previous ones. There is a positive association between article length and citations, since this length may be related to greater scientific complexity and higher methodological quality. In addition, larger articles tended to contain more information, which, in turn, increased the possibility of some of the material being cited [37]. Our findings corroborate this information; the highest mean number of WoS citations per year in terms of studies published occurred in the last decade. The number of references cited was also higher in these studies, a fact that may be related to the greater amount of works available in the literature and the non-establishment of reference limits by the journals.

\subsection{Authors, Institutions, and Countries}

According to the study by Li et al., the US and China were the countries with the largest number of publications on air pollution [21]. This field of research is characterized by a high degree of international cooperation [21]; our results show that more than $40 \%$ of the studies were published by authors from institutions in at least two countries. Specifically, the US and China presented this characteristic in the vast majority of their publications. Here, we would like to highlight the study by Cole-Hunter et al., which attracted the participation of 10 authors from institutions in five countries (Spain, Canada, Switzerland, the US, and England) [38].

The number of authors and institutions per study was significantly higher in more recently publications (after 2008) compared to the previous period; this may have occurred due to the increase in collaborative research networks. The increase in the number of authors has also been reported in studies in other areas $[39,40]$.

The institutions with the largest number of funded studies belonged to the State Council of China. Such institutions, such as the National Natural Science Foundation of China, seek to promote and fund basic and applied research in China. Studies have shown a difference in the impact (number of citations) of funded studies compared to those without funding $[41,42]$. However, the present study did not identify any such differences.

The main collaboration network was established by the researchers Audrey de Nazelle and Mark J Nieuwenhuijsen, who authored the largest number of publications in this analysis, representing a network involving more than 20 co-authors. The joint affiliation of these was the Center for Research in Environmental Epidemiology (CREAL) in Barcelona, Spain. Authors' participation in research groups and international collaboration networks allows 
for increased productivity and improved research quality [43]. Above all, international collaboration for research on the issue of outdoor air pollution, which is a public health concern, is necessary [44]. Peking University was the institution with the largest number of publications on the subject; one of the oldest universities in China, it has a robust history of scientific research.

Europe proved to be a more productive continent in terms of rankings related to environmental concerns, as this is a noted domain for most European countries [45]. In addition, studies involving European institutions tended to have funding, and this promoted research.

While analyzing the scientific production relevant to this study's selected subject, it was noted that researchers from China were highly productive, and they showed high interest in the subject due to the alarming levels of pollution observed at the venue of the Olympic Games in 2008. However, even four years after the 2016 Olympic Games in Rio de Janeiro, there were only three publications on the air quality in that city. For example, the greatest attention was paid to water pollution in places where the sailing competitions had taken place [45]. Institutions in South America presented only ten publications, and nine of these were from Brazilian institutions.

\subsection{Journals}

In a bibliometric study of global pollution research between 2005 and 2014, Kolle and Thyavanahalli highlighted that some journals (e.g., Atmospheric Environment, Environmental Health Perspectives, and Science of the Total Environment) were the most active, presenting a large number of publications [46]. A similar result was observed in the study by Zell et al., which analyzed publications on air pollution between 1955 and 2006 [36]. Considering the published literature on outdoor pollution and respiratory health, Environmental Health Perspectives was the most active journal [44]. In contrast to these results, our results showed that these journals were among the five with the highest number of published articles on air quality in outdoor sports and exercise. These journals play an important role in disseminating scientific knowledge about air pollution.

Although a subject with a large number of publications (mainly in the Environmental Sciences area), air pollution has also been a relevant topic for medical journals, most of which are classified in the medical area according to the SCImago Journal \& Country Rank.

\subsection{Strengths and Limitations}

Ours is the first study to assess research activity in the field of outdoor air pollution with special emphasis on environments used for exercise and sports practice; we performed 24 analyses with regard to several characteristics of the publications. The study results identified areas of research and exposed the concerns of scientists with regard to air pollution and environmental aspects; these are important factors that should be analyzed by managers and government officials. Such analyses will facilitate the creation of public policies for preserving the environment and reducing the population's exposure to respiratory risks. Our study does not delve deeper into the analyses with respect to the methods and results, so new reviews with this objective are suggested.

Search strategies are another issue that should be taken into consideration. Our analysis used data from and about journals indexed in five major databases; however, studies published in non-indexed journals may have been excluded from the analysis. This is a limitation, especially with regard to journals published in countries such as China and India, which present a strong concern for public health due to air pollution [44].

\section{Conclusions}

Our results, based on more than 20 analyses related to the publications, journals, and authors, provide a quantitative perspective and overview of research about outdoor air quality of environments used for exercise and sports practice. 
The analysis of outdoor air quality of environments used for exercise and sports practice has been a concern for researchers for about 50 years; however, interest in the subject increased from 2009 onward, and the greatest number of publications were produced in the last decade. It is observed that most of these publications were produced by researchers from institutions in the US and China, and these two countries had the largest number of funding agencies. The publications showed a focus on pollutants as well as subjects related to human health, besides physical exercise, physical activity, and sports.

The bibliometric approaches allowed us to recognize that the most productive researchers belong to European institutions and have demonstrated diverse institutional affiliations, which widens the network of collaboration and possibilities of research development.

Author Contributions: Conceptualization, A.A. and F.H.D.; methodology, F.H.D. and G.T.V.; investigation, F.H.D.; resources, F.H.D.; data curation, F.H.D.; writing-original draft preparation, F.H.D.; writing-review and editing, F.H.D and A.A.; visualization, G.T.V.; supervision, A.A.; project administration, A.A.; funding acquisition, A.A. All authors have read and agreed to the published version of the manuscript.

Funding: This research was funded by the FAPESC (Research and Innovation Support Foundation of the State of Santa Catarina) for financial support through research (Project n. 2287/ PAP 04/2014). This study was financed in part by the Coordenação de Aperfeiçoamento de Pessoal de Nível Superior-Brazil (CAPES)-Finance Code 001.

Conflicts of Interest: The authors declare no conflict of interest.

\section{References}

1. Fuoco, F.C.; Stabile, L.; Buonanno, G.; Trassiera, C.V.; Massimo, A.; Russi, A.; Mazaheri, M.; Morawska, L.; Andrade, A. Indoor air quality in naturally ventilated Italian classrooms. Atmosphere 2015, 6, 1652-1675. [CrossRef]

2. Stabile, L.; Massimo, A.; Canale, L.; Russi, A.; Andrade, A.; Dell'Isola, M. The effect of ventilation strategies on indoor air quality and energy consumptions in classrooms. Buildings 2019, 9, 110. [CrossRef]

3. Andrade, A.; Dominski, F.H.; Pereira, M.L.; de Liz, C.M.; Buonanno, G. Fitness centers demonstrate CO2 concentration levels above recommended standards. Acta Sci. Health Sci. 2018, 40, e35768. [CrossRef]

4. Andrade, A.; Dominski, F.H.; Pereira, M.L.; de Liz, C.M.; Buonanno, G. Infection risk in gyms during physical exercise. Environ. Sci. Pollut. Res. Int. 2018, 25, 19675-19686. [CrossRef]

5. Franchini, M.; Mannucci, P.M.; Harari, S.; Pontoni, F.; Croci, E. The health and economic burden of air pollution. Am. J. Med. 2015, 128, 931-932. [CrossRef]

6. Lee, I.M.; Shiroma, E.J.; Lobelo, F.; Puska, P.; Blair, S.N.; Katzmarzyk, P.T. Effect of physical inactivity on major non-communicable diseases worldwide: An analysis of burden of disease and life expectancy. Lancet 2012, 380, 219-229. [CrossRef]

7. World Health Organization (WHO). Global Health Risks: Mortality and Burden of Disease Attributable to Selected Major Risks; WHO: Geneva, Switzerland, 2009.

8. Andrade, A.; Vilarino, G.T.; Bevilacqua, G.G. What is the effect of strength training on pain and sleep in patients with fibromyalgia? Am. J. Phys. Med. Rehabil. 2017, 96, 889-893. [CrossRef]

9. Gebel, K.; Ding, D.; Chey, T.; Stamatakis, E.; Brown, W.J.; Bauman, A.E. Effect of moderate to vigorous physical activity on all-cause mortality in middle-aged and older Australians. JAMA Intern. Med. 2015, 175, 970-977. [CrossRef]

10. Janssen, I.; LeBlanc, A.G. Systematic review of the health benefits of physical activity and fitness in school-aged children and youth. Int. J. Behav. Nutr. Phys. Act. 2010, 7, 40. [CrossRef]

11. Garber, C.E.; Blissmer, B.; Deschenes, M.R.; Franklin, B.A.; Lamonte, M.J.; Lee, I.M.; American College of Sports Medicine. Quantity and quality of exercise for developing and maintaining cardiorespiratory, musculoskeletal, and neuromotor fitness in apparently healthy adults: Guidance for prescribing exercise. Med. Sci. Sports. Exerc. 2011, 43, 1334-1359. [CrossRef]

12. Tainio, M.; de Nazelle, A.J.; Götschi, T.; Kahlmeier, S.; Rojas-Rueda, D.; Nieuwenhuijsen, M.J.; Thiago, H.S.; Paul, K.; James, W. Can air pollution negate the health benefits of cycling and walking? Prev. Med. 2016, 87, 233-236. [CrossRef] [PubMed]

13. Andrade, A.; Dominski, F.H. Indoor air quality of environments used for physical exercise and sports practice: Systematic review. J. Environ. Manag. 2018, 15, 577-586. [CrossRef] [PubMed]

14. Carlisle, A.; Sharp, N. Exercise and outdoor ambient air pollution. Br. J. Sports Med. 2001, 35, 214-222. [CrossRef] [PubMed]

15. Hajian, M.; Mohaghegh, S. Indoor Air Pollution in Exercise Centers. IJMTFM 2015, 5, 22-31. [CrossRef]

16. Brook, R.D.; Rajagopalan, S.; Pope, C.A., 3rd; Brook, J.R.; Bhatnagar, A.; Diez-Roux, A.V.; American Heart Association Council on Epidemiology and Prevention, Council on the Kidney in Cardiovascular Disease, and Council on Nutrition, Physical Activity and Metabolism. Particulate matter air pollution and cardiovascular disease: An update to the scientific statement from the American Heart Association. Circulation 2010, 121, 2331-2378. [CrossRef] 
17. Chan, S.H.; Van Hee, V.C.; Bergen, S.; Szpiro, A.A.; DeRoo, L.A.; London, S.J.; Sandler, D.P.; Julian, D.M.; Joel, D.K. Long-term air pollution exposure and blood pressure in the sister study. Environ. Health Perspect. 2015, 123, 951-958. [CrossRef]

18. Gauderman, W.J.; Urman, R.; Avol, E.; Berhane, K.; McConnell, R.; Rappaport, E.; Roger, C.; Fred, L. Association of improved air quality with lung development in children. N. Engl. J. Med. 2015, 372, 905-913. [CrossRef]

19. Huang, S.K.; Zhang, Q.; Qiu, Z.; Chung, K.F. Mechanistic impact of outdoor air pollution on asthma and allergic diseases. J. Thorac. Dis. 2015, 7, 23-33. [CrossRef]

20. Giles, L.V.; Koehle, M.S. The health effects of exercising in air pollution. Sports Med. 2014, 44, 223-249. [CrossRef]

21. Li, Y.; Wang, Y.; Rui, X.; Li, Y.; Li, Y.; Wang, H.; Jian, Z.; Yindong, T. Sources of atmospheric pollution: A bibliometric analysis. Scientometrics 2017, 112, 1025-1045. [CrossRef]

22. Andrade, A.; Dominski, F.H.; Coimbra, D.R. Scientific production on indoor air quality of environments used for physical exercise and sports practice: Bibliometric analysis. J. Environ. Manag. 2017, 196, 188-200. [CrossRef] [PubMed]

23. Coimbra, D.R.; Dominski, F.H.; Correia, C.K.; Andrade, A. Scientific production in Sports Science Journals: Bibliometric analysis. Rev. Bras. Med. Esport. 2019, 25, 88-93. [CrossRef]

24. Brimblecombe, P.; Grossi, C.M. The bibliometrics of atmospheric environment. Atmos. Environ. 2009, 43, 9-12. [CrossRef]

25. Habibzadeh, F.; Yadollahie, M. Are shorter article titles more attractive for citations? Crosssectional study of 22 scientific journals. Croat. Med. J. 2010, 51, 165-170. [CrossRef]

26. McConnell, R.; Berhane, K.; Gilliland, F.; London, S.J.; Islam, T.; Gauderman, W.J.; Edward, A.; Helene, G.M.; John, M.P. Asthma in exercising children exposed to ozone: A cohort study. Lancet 2002, 359, 386-391. [CrossRef]

27. Wang, S.; Zhao, M.; Xing, J.; Wu, Y.; Zhou, Y.; Lei, Y.; Kebin, H.; Lixin, F.; Jiming, H. Quantifying the air pollutants emission reduction during the 2008 Olympic Games in Beijing. Environ. Sci. Technol. 2010, 44, 2490-2496. [CrossRef]

28. Rojas-Rueda, D.; de Nazelle, A.; Tainio, M.; Nieuwenhuijsen, M.J. The health risks and benefits of cycling in urban environments compared with car use: Health impact assessment study. BMJ 2011, 343, 4521. [CrossRef]

29. Rich, D.Q.; Kipen, H.M.; Huang, W.; Wang, G.; Wang, Y.; Zhu, P.; Ohman-Strickland, P.; Hu, M.; Philipp, C.; Diehl, S.R.; et al. Association between changes in air pollution levels during the Beijing Olympics and biomarkers of inflammation and thrombosis in healthy young adults. JAMA 2012, 307, 2068-2078. [CrossRef]

30. Panis, L.I.; De Geus, B.; Vandenbulcke, G.; Willems, H.; Degraeuwe, B.; Bleux, N.; Vinit, M.; Isabelle, T.; Romain, M. Exposure to particulate matter in traffic: A comparison of cyclists and car passengers. Atmos. Environ. 2010, 44, 2263-2270. [CrossRef]

31. Wang, W.; Primbs, T.; Tao, S.; Simonich, S.L.M. Atmospheric particulate matter pollution during the 2008 Beijing Olympics. Environ. Sci. Technol. 2009, 43, 5314-5320. [CrossRef]

32. Wang, T.; Xie, S. Assessment of traffic-related air pollution in the urban streets before and during the 2008 Beijing Olympic Games traffic control period. Atmos. Environ. 2009, 43, 5682-5690. [CrossRef]

33. Marshall, J.D.; Brauer, M.; Frank, L.D. Healthy neighborhoods: Walkability and air pollution. Environ. Health Perspect. 2009, 117, 1752-1759. [CrossRef] [PubMed]

34. Jacobs, L.; Nawrot, T.S.; De Geus, B.; Meeusen, R.; Degraeuwe, B.; Bernard, A.; Sughis, M.; Nemery, B.; Panis, L.I. Subclinical responses in healthy cyclists briefly exposed to traffic-related air pollution: An intervention study. Environ. Health $2010,9,64$. [CrossRef] [PubMed]

35. Wayne, W.S.; Wehrle, P.F.; Carroll, R.E. Oxidant air pollution and athletic performance. JAMA 1967, 199, 901-904. [CrossRef] [PubMed]

36. Zell, H.; Quarcoo, D.; Scutaru, C.; Vitzthum, K.; Uibel, S.; Schöffel, N.; Mache, S.; Groneberg, D.A.; Spallek, M.F. Air pollution research: Visualization of research activity using density-equalizing mapping and scientometric benchmarking procedures. $J$. Occup. Med. Toxicol. 2010, 5, 5. [CrossRef] [PubMed]

37. Falagas, M.E.; Zarkali, A.; Karageorgopoulos, D.E.; Bardakas, V.; Mavros, M.N. The impact of article length on the number of future citations: A bibliometric analysis of general medicine journals. PLoS ONE 2013, 8, e49476. [CrossRef]

38. Cole-Hunter, T.; Weichenthal, S.; Kubesch, N.; Foraster, M.; Carrasco-Turigas, G.; Bouso, L.; Martínez, D.; Westerdahl, D.; de Nazalle, A.; Nieuwenhijsen, M. Impact of traffic-related air pollution on acute changes in cardiac autonomic modulation during rest and physical activity: A cross-over study. J. Expo. Sci. Environ. Epidemiol. 2016, 26, 133-140. [CrossRef]

39. Sheridan, G.; Wisken, E.; Hing, C.; Smith, T. A bibliometric analysis assessing temporal changes in publication and authorship characteristics in The Knee from 1996 to 2016. Knee 2018, 25, 213-218. [CrossRef]

40. Geminiani, A.; Ercoli, C.; Feng, C.; Caton, J.G. Bibliometrics study on authorship trends in periodontal literature from 1995 to 2010. J. Periodontol. 2014, 85, 136-143. [CrossRef]

41. Shen, C.C.; Hu, Y.H.; Lin, W.C.; Tsai, C.F.; Ke, S.W. Research impact of general and funded papers: A citation analysis of two ACM international conference proceeding series. Online Information Rev. 2016, 40, 472-480. [CrossRef]

42. Wang, J.; Shapira, P. Is there a relationship between research sponsorship and publication impact? An analysis of funding acknowledgments in nanotechnology papers. PLoS ONE. 2015, 10, e0117727. [CrossRef] [PubMed]

43. Kyvik, S.; Reymert, I. Research collaboration in groups and networks: Differences across academic fields. Scientometrics 2017, 113, 951-967. [CrossRef] [PubMed]

44. Sweileh, W.M.; Al-Jabi, S.W.; Sa'ed, H.Z.; Sawalha, A.F. Outdoor air pollution and respiratory health: A bibliometric analysis of publications in peer-reviewed journals (1900-2017). Multidiscip. Respir. Med. 2018, 13, 15. [CrossRef] [PubMed] 
45. Dragos, C.M.; Dragos, S.L. Bibliometric approach of factors affecting scientific productivity in environmental sciences and ecology. Sci. Total Environ. 2013, 449, 184-188. [CrossRef] [PubMed]

46. Kolle, S.R.; Thyavanahalli, S.H. Global research on air pollution between 2005 and 2014: A bibliometric study. Collect. Build. 2016, 35, 84-92. [CrossRef] 